\title{
Intra-banking competition in Ecuador: new evidence using panel data approach
}

\author{
Javier Solano \\ Universidad Metropolitana, Sede Machala, Ecuador \\ Segundo Camino-Mogro \\ ESAI Business School-Universidad Espiritu Santo, \\ Samborondón, Ecuador; Ecuadorian Political Economy Lab (EPEL), \\ Guayaquil, Ecuador and Dirección Nacional de Investigación y Estudios, \\ Superintendencia de Compañias, Valores y Seguros, Guayaquil, Ecuador, and \\ Grace Armijos-Bravo \\ ESAI Business School - Universidad Espiritu Santo, Samborondón, Ecuador
}

\section{Intra-banking competition}

Received 31 May 2019

Revised 25 June 2019

18 July 2019

Accepted 2 August 2019

\begin{abstract}
Purpose - Banks are institutions that inject money in the economy and help to boost it when there are problems in some markets, especially in productive sectors. In this way, analysing the competition in this sector is an important tool for policymakers as non-competitive behaviour could affect the financial system and economy. The purpose of this paper is to measure the degree of competition in the Ecuadorian private banking sector divided by size, from 2000 to 2015, using panel data collected by the official regulator institution.
\end{abstract}

Design/methodology/approach - The authors applied the model proposed by Panzar and Rosse (1987) and its $H$-statistic using a reduced price and revenue equation estimated by pooled ordinary least squares, fixed effects, random effects, feasible generalised fixed effects and panel correction standard errors (PCSE).

Findings - The authors show that given the presence of some problems in data such as heteroskedasticity and autocorrelation, the most appropriate technique is PCSE. The authors also found robust evidence supporting that large banks compete in a monopolistic market, small and medium-sized banks operate in monopolistic competition, and Ecuadorian small, medium-sized and large banks stay in long-run equilibrium.

Originality/value - This paper contributes to the actual literature of competition degree in two ways. First, different from traditional papers, we do not control by size; so, we divided the analysis by size, because in Ecuador and also in many developing countries, bank's competition is different for each group of size because the levels of liquidity, risk and other indicators are different from one group to another. Second, we show the robustness of the results using a scaled and unscaled equation, using many controls and using five methods to contrast the competition degree.

Keywords Market concentration, Competition, Banks

Paper type Research paper

(C) Javier Solano, Segundo Camino-Mogro and Grace Armijos-Bravo. Published in the Journal of Economics, Finance and Administrative Science. Published by Emerald Publishing Limited. This article is published under the Creative Commons Attribution (CC BY 4.0) license. Anyone may reproduce, distribute, translate and create derivative works of this article (for both commercial and non-commercial purposes), subject to full attribution to the original publication and authors. The full terms of this license may be seen at http://creativecommons.org/licences/by/4.0/legalcode

JEL classification - G21, L1, D40, L80

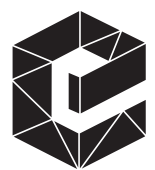

Journal of Economics, Finance and Administrative Science Vol. 25 No. 50,2020 Vol. 25 No. 50,2020
pp. $295-319$ pp. 295-319
Emerald Publishing Limited 2218-0648 DOI 10.1108/JEFAS-05-2019-0081 
JEFAS

25,50

296

\section{Introduction}

The private banking market is one of the most important sectors in developed and developing economies and is now growing to be a sector of interest to policymakers because banks are institutions that inject money in the economy and help to boost it when there are problems in some industries, especially in productive sectors. Also, Goddard and Wilson (2009) mention that most households and businesses engage in transactions with banks, for deposits, loans and other financial services, and banks perform a vital economic function in channelling funds from savers to investors and in the monetary policy transmission mechanism.

In this sense, banking competition helps to foster higher economic growth (Buchs and Mathisen, 2005). It enhances efficiency, as it compels managers to cut down on costs to remain profitable (Claessens and Laeven, 2004). Also, banking competition facilitates banks to satisfy the needs of the public at a reduced social cost and enhances the efficiency of the production and quality of financial services and products. For this, Claessens and Laeven (2004) argued that a reduction in the level of competition in the banking sector will make provision of financial services costly, leading to less financing which impedes economic growth.

According to this, Bikker et al. (2012), Yildirim and Philippatos (2007) and De Bandt and Davis (2000) analyse not only the competition in the banking industry but also the banking competition by size group and conclude that large and small banks (not medium-sized banks) operate in monopolistic competition in many countries. However, other authors such as Berger and Black (2011), De Haan and Poghosyan (2012) and Uchida et al. (2008) argue that banks by size group have different characteristics to lend to different firm sizes; this situation depends on the type of credit and the type of firm that borrows.

The main purpose of this study is to assess the competition and analyses if there are differences between sizes (regarding competition) in the private banking sector using a nonstructural approach developed by Panzar and Rosse, we compare four estimation techniques to obtain the competition degree for each group of banks segmented by size and we also test if the market is in long-run equilibrium. Camino-Mogro and Armijos-Bravo (2018) assess the banking competition in Ecuador controlling by size; however, it is notorious in Ecuador that private banks compete not only in the entire market but also in sizes, that is, small banks have their credit segment, different from large and medium-sized banks. In this sense, we compared banks by size using a reduced price and revenue equation, to get robust evidence intra-banking competition.

This paper contributes to the actual literature of competition degree in two ways. First, different to traditional papers, we assess the degree of competition in the Ecuadorian private banking sector using the bank size classification and take advantage of this issue since competition by size could be different because there is a banking specialisation in terms of size, levels of liquidity, risk and other indicators that are different from one group to another. Second, we show the robustness of our results using a scaled and unscaled equation using many controls and similar to Apergis et al. (2016), we use the panel-corrected standard error and feasible generalised least squares to contrast the value of $H$-statistic obtained by pooled ordinary least squares (POLS), fixed effects (FE) and random effects (RE).

Another important issue is that Ecuador is a dollarised emerging economy and unique in South America, with some financial system characteristics such as it is not allowed that a foreign bank has more than $50 \%$ participation on a national bank; there is a tax applied on the exit of local currency to foreign locations which decreases the participation of foreign firms in the financial system; it is not allowed that the Central Bank acts as a lender of last resort; there is a liquidity fund constituted from contributions of financial institutions, and 
banks also have the obligation to set up a guarantee trust equivalent to $100 \%$ of its assets. All these applied regulations generate an important interest in studying the level of private banking competition in Ecuador, to be able to know whether, in addition to contributing with a healthy financial system, they helped or not to improve the competition.

Using annual data on the private banking sector in Ecuador for the period 2000-2015, we find that bank size decreases competition, in particular, large banks operate in a monopolistic environment, while medium-sized and small banks operate in a monopolistic competition but tend to be perfect competition. Our results show that the degree of competition is different by bank size, in this line, we propose the analysis of banking competition by the disaggregation of group size when there are huge differences in bank characteristics across size because of, for example, the different types of loans offered by each bank (specialisation).

The paper is structured as follows: Section 2 gives an overview of the Ecuadorian private banking sector. Section 3 provides a literature review about banking competition, banking concentration, and bank size. In Section 4, we present our data and the empirical method used. We provide our empirically results in Section 5. Finally, Section 6 concludes.

\section{Overview of the Ecuadorian private banking sector}

Ecuador is a dollarised country since 2000, and after this monetary process, some regulations were applied to the financial system concerning banking supervision, competition, public-available risk rating, microfinance risk and control of market liquidity risk to prevent other banking crisis. However, those regulations adopted since 2000 have not improved the competition degree because these policies were done only to strengthened the financial system, one proof of this is that the four major banks concentrate around $60 \%$ of deposits and loans (Uzcátegui-Sánchez et al., 2018; Salgado, 2010).

The Ecuadorian financial system is composed of public and private institutions authorised and regulated by Superintendence of Banks (SB: the institution at the country level that regulates both public and private banking institutions). In this financial system, the subsectors, public banks, private banks, financial companies, savings and credit cooperatives and mutualists (Superintendencia de Bancos del Ecuador, 2016) operate under different conditions. Public and private banks are the most important subsectors, and there are marked differences between them. Salgado (2010) mentions that the private banking sector operates around $75 \%$ of total deposits and loans of the financial system, different for the public banks that operates around $13 \%$ of those accounts. Because of these differences, in this research, we analyse only the private banking sector because the dollarisation system was adopted in 2000-2015.

Additionally, in Ecuador, the SB classifies the banks' size by their total assets using the percentiles methodology according to the data of the participation of the total asset, resulting in large $(>36 \%)$, medium-sized $(12 \%<36 \%)$ and small $(<12 \%)$. In this vein, Bain (1951) argues that few and large firms (high concentration) are easier to commit anticompetitive behaviour (collusion). Large banks have a big difference in assets, deposits, loans and revenues compared to medium-sized and small banks, and also the market share is little fragmented; regarding deposits, large banks have around $65 \%$ of market share, medium-sized banks around $32 \%$ and small banks around 3\%. In Figure 1, we show the differences in means between bank size in total assets, deposits and loans, where it is seen that large banks have around 4 times more the total assets, loans and deposits than mediumsized banks and around 24 times more than small banks.

Another difference between sizes, particularly in 2015, is that large banks are mostly servicing corporate commercial loans (around 40\%) and small and medium-sized enterprise 

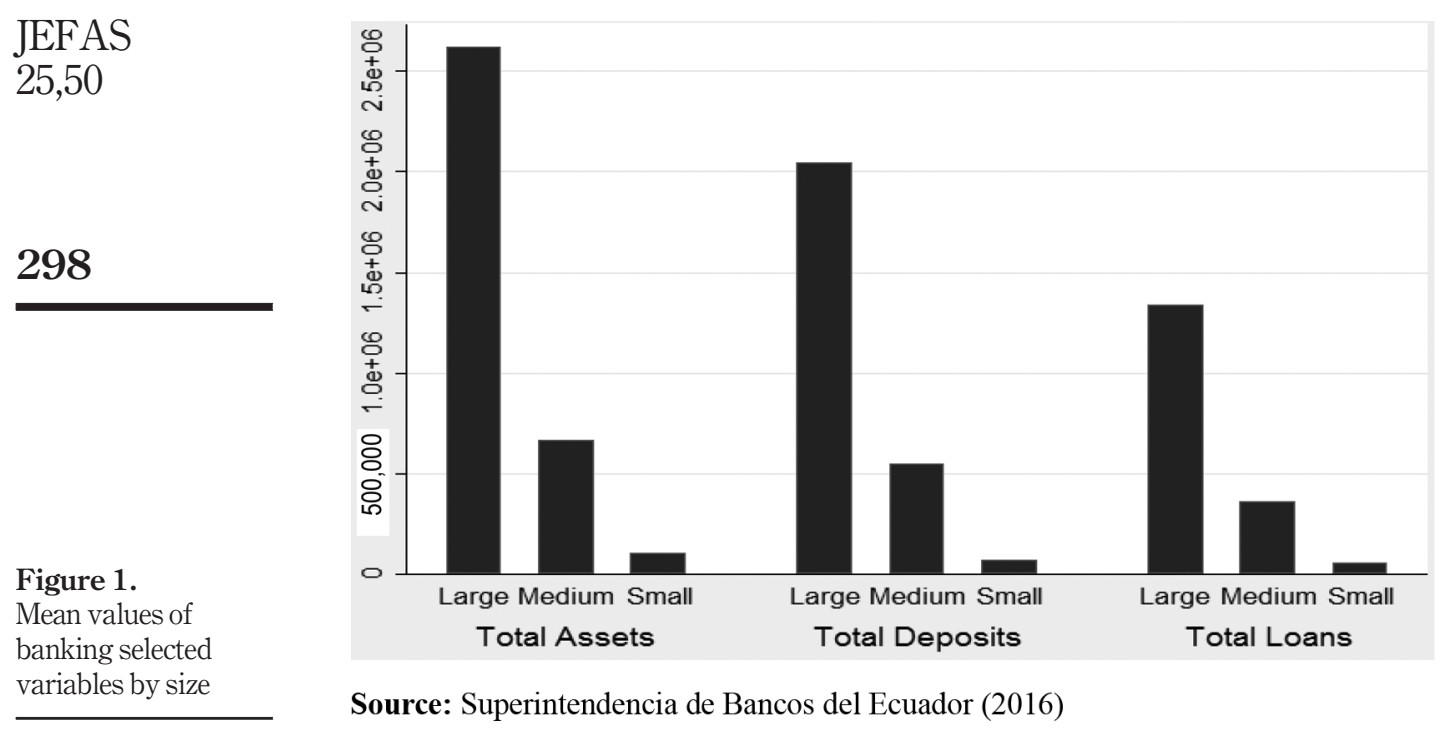

Source: Superintendencia de Bancos del Ecuador (2016)

(SME) loans (around 16\%) and small banks attend in major microcredits (around 55\%) that are loans with a higher level of risk than corporate, entrepreneurship and SME loans. This difference is because of liquidity, solvency, positioning and risk.

\section{Literature review}

In most countries, there is a bank classification by size; some countries use the criteria of the number of employees, financial revenues, total assets, fixed assets and others. In Ecuador, the SB classifies bank size by total assets, where there are some differences across size groups with loan target being one of the most important.

In this line, large, medium and small banks could compete in different ways; Berger and Black (2011) found that large banks do not have advantages over small banks in lending to relatively large firms. However, other studies examined the differences in earnings between banks of different sizes and concentrations in the banking sector in the USA, this research concludes that large banks located in concentrated markets tend to have higher volatility in earnings during the financial crisis (De Haan and Poghosyan, 2012). In Japan, an empirical study suggests that large banks usually borrow to large firms as well as large banks do not necessarily have a comparative advantage in extending transaction-based lending. The study also showed that small banks tend to have stronger relationships with their borrowers compared to large banks (Uchida et al., 2008).

According to Berger et al. (2005), large banks are less willing to lend to firms about which they have limited information; they also found that small banks have higher ability to allocate capital to risky borrowers; small banks are better in collecting and acting on "soft" information. Stever (2007) argues that small banks are riskier because of their limited ability to diversify. His data refers to the US bank holding companies between 1986 and 2003 and also reports that small banks have fewer opportunities to diversify, which forces them to probably pick borrowers whose assets have relatively low credit risk to make loans that are backed by more collateral. This lower diversification, in turn, may result in higher earnings volatility. 
The diversity in the market share in which the banks compete generates an average effect when studying the concentration. Castellanos (2010), to reduce this impact, uses a division by size when analysing the power of the banking sector in Guatemala. One of the techniques used in the new industrial organisation to evaluate competition in the banking sector is the Panzar and Rosse (P-R) model (1978), which is a non-structural approach and formal measure to evaluate the degree of competition.

Some seminal research studies about the competition in the banking sector, such as Shaffer (1985), Nathan and Neave (1989), Perrakis (1991) and Molyneux et al. (1994), used the $\mathrm{P}-\mathrm{R}$ model showing various interpretations of $H$-statistics. In particular, the $H$-statistic is not positive if the firm is a profit-maximising monopolist or an oligopoly with short-term conjectural variations (Panzar and Rosse, 1987).

Durán et al. (2009) investigated the competitiveness of the set of intermediaries that constitute the Costa Rican financial system and the temporal behaviour of its structure. Applying the P-R and Shaffer approaches, some conclusions are inferred regarding the type of industrial organisation of the financial system. The results obtained reveal that within the Costa Rican financial system, large banks and small banks operate under perfect competition conditions.

Bikker et al. (2012), Nathan and Neave (1989), Claessens and Laeven (2004) and De Bandt and Davis (2000) are some of the authors of numerous studies that have been generated with the application of this model to measure the degree of competition in the banking sector, where banks are treated as producers of intermediation services through inputs of factors such as labour, capital and financial capital.

There is a recent and growing literature that analyses the banking competition using the $\mathrm{P}-\mathrm{R}$ model; the results vary according to the country analysed, the period of time and the circumstances such as post- and pre-crisis periods or changes in government; for example, of recent literature, see Sabir and Qayyum (2018), Nguyen et al. (2018), Bikker and Spierdijk (2017), Apergis et al. (2016), Shaffer and Spierdijk (2015), Barbosa et al. (2015), Anginer et al. (2014) and Moch (2013); these studies also differ in the magnitude of the $H$-statistic because, in most cases, the result is an $H$-statistic between 0 and 1 , suggesting a monopolistic competition; nevertheless, the results in many cases depend on using a revenue equation or price equation[1].

In Ecuador, there are a few pieces of evidence that analyse the competition degree of the banking system using a non-structural approach of the new industrial organisation. Camino-Mogro and Armijos-Bravo (2018) assess empirically the competitive conditions in the private banking sector in Ecuador from 2000 to 2015 and found that that private banks in Ecuador operate under monopolistic competition; in addition, the competition increase during the 2007-2015 period; this study do not differentiate the bank size and only use a price equation. Another study that analyses bank competition, but in other contexts, is VeraGilces et al. (2020). They use the P-R (H-statistic) to test whether this measure is a determinant of banking profitability in Ecuador.

Finally, evidence differentiate the banking competition by size group; some of these are Bikker et al. (2012), Yildirim and Philippatos (2007) and De Bandt and Davis (2000), all of these research works conclude that large and small banks (not medium-sized banks) operate in monopolistic competition in many countries. However, this study divided the size group in three (including medium-sized banks) and contributes to the literature given evidence of banking competition by size in concordance with the idea of non-single market product. In addition, we use five different methods to estimate the competition degree by bank size, different from previous studies that only use classical methods such as POLS, FE and RE, and we also prefer the non-typical methods to use the competition degree ( $H$-statistic). 
JEFAS

25,50

300

\subsection{Theoretical model of Panzar-Rosse}

We follow the derivation of the P-R model used by Camino-Mogro and Armijos-Bravo (2018) and Buchs and Mathisen (2005). To assess competition, they consider the bank maximisation problem, where bank $i$ has total revenue $(R)$ and total costs $(C)$. Both are functions that depend on the level of production $(y)$ and on the exogenous variables $(z, x)$, where $z$ affects revenues and $x$ costs, but also on variables that affect both cost and revenues functions such as the number of firms $(n)$, and a vector of input prices $(p)$ that affects the cost function.

$$
\begin{aligned}
& R_{i}=R_{i}\left(y_{i}, n, z_{i}\right) \\
& C_{i}=C_{i}\left(y_{i}, p_{i}, x_{i}\right)
\end{aligned}
$$

Banks maximise their profits in the point where marginal revenue $R_{i}^{\prime}\left(\mathrm{y}_{\mathrm{i}}, n, z_{\mathrm{i}}\right)$ equals marginal costs, $\mathrm{C}_{i}^{\prime}\left(y_{i}, p_{i}, x_{i}\right)$, which can be seen in the following equation:

$$
R_{i}^{\prime}\left(y_{i}, n, z_{i}\right)-\mathrm{C}_{i}^{\prime}\left(y_{i}, p_{i}, x_{i}\right)=0
$$

The production $(y)$ of the bank $i$ depends on a set of exogenous variables $(z)$ that affect revenue, a vector of input prices $(p)$ and exogenous variables $(x)$ that affect the cost function. Therefore, the equilibrium production is written as equation (4). To obtain the reduced form of the revenue equation, which is a product of equilibrium production and price level, we replace equation (4) in equation (1) and assuming that $n$ is endogenous in the model, we get equation (5).

$$
\begin{gathered}
y_{i}^{*}=y_{i}^{*}\left(z_{i}, p_{i}, \mathrm{x}_{\mathrm{i}}\right) \\
R_{i}^{*}=R_{i}^{*}\left(z_{i}, p_{i}\right)
\end{gathered}
$$

As mentioned before, the $\mathrm{P}-\mathrm{R}$ model provides the $H$-statistic which is a competition measure. This statistic is the sum of elasticities of firm total revenue with respect to the changes in input prices, as shown in equation (6):

$$
H=\sum \frac{\partial R_{i}^{*}}{\partial p_{\mathrm{i}}} \frac{p_{\mathrm{i}}}{R_{i}^{*}}
$$

where $\left(\partial p_{i}\right)$ represents the changes in input prices and $\left(\partial R_{i}^{*}\right)$ represents the equilibrium revenues earned by the bank $i$. $H$-statistic lies between less infinity and one. Thus, it can take zero or negative values when the market structure is a monopoly, collusive oligopoly or a conjectural variation of oligopoly; this scenario may occur when an increase in input prices $(p)$ increases the marginal cost - reducing the level of equilibrium production, total revenues and profits. When the $H$-statistics lies between zero and the unity, banks compete under monopolistic competition; in this scenario, total revenues increase less than proportional changes in input prices ( $p$ ); this result is considered as the most plausible as mentioned by Bikker and Haaf (2002). Finally, the $H$-statistic can be one if any increase in input prices $(p)$ increases marginal and average costs in the same proportion without changing the equilibrium product of banks. Under this situation, banks that are inefficient (cannot solve 
the problem of changes in input prices) will be forced out of the market. Table 1 shows the different values that $H$-statistic can take.

The P-R model and its $H$-statistic rely upon the assumption that the market must be in the long-run equilibrium. To test whether the market under analysis is in equilibrium, we follow Shaffer (1985) and Nathan and Neave (1989) who suggest regressing the same equation of the P-R model but using the return on assets (ROA) as the dependent variable instead. From this regression, the $E$-statistic (a test where $E=0$ ) is derived and it is the sum of elasticities of the rate of return concerning input prices. If $E<0$, then there is an unbalance in the long run, and if $E=0$, the market is in the long-run equilibrium. Table 2 shows the different values the $E$-statistic can take.

Even we follow the model proposed by Buchs and Mathisen (2005), our research differs from that and other previous studies, as we focus on the relationship between bank size and competition level. For this, we apply the model to each bank size group instead of on the whole sample of banks; thus, we reduce the problem mentioned by Bikker et al. (2012) that only unscaled revenue equations provide a valid measure of banking competition. In this sense, estimating a single equation for all banks without controlling for size differences may not be a good alternative as we are assuming that there are no different characteristics according to bank size, which for sure is not the case.

\section{Methods}

\subsection{Materials}

In this study, we use the financial balance data set of banks reported in SB from 2000 to 2015 (annually). An unbalanced panel data was built with 383 observations distributed according to the banks' size. As we mentioned in Section 1, we chose to split the sample into three groups according to size, instead of a whole sample with size dummies, because of the different characteristics that each type of bank (small, medium and large) has in the Ecuadorian context. Also, using three size subsamples allow us to work with the unscaled revenue equation, as suggested by Bikker et al. (2012). The information regarding the three subsamples is shown in Table 3.

\begin{tabular}{ll}
\hline$H$ values & Implicit market structure \\
\hline$H \leq 0$ & Monopoly, collusive monopoly, conjectural variations of oligopoly \\
$0<H<1$ & Monopolistic competition \\
$H=1$ & Perfect competition \\
& Natural monopoly in perfect market
\end{tabular}

Source: Buchs and Mathisen (2005)

Table 1.

Panzar and Rosse $H$ statistic

\begin{tabular}{lr}
\hline$E$ values & Equilibrium test \\
\hline$E=0$ & Equilibrium \\
$E<0$ & Disequilibrium
\end{tabular}

Sources: Bikker and Haaf (2002); Gelos and Roldós (2004)

Table 2.

Long-run equilibrium 
JEFAS

25,50

302

This size division results in banks that have no observations during the whole period or parts of it mainly because some banks closed their operations. However, we have decided to include them in the analysis because in some cases these banks belong to the "large and medium-size" group.

To build the data set, only private banks, not public ones, were considered since business management differs from one to another. Private banks have revenues from other services such as credit cards, demand deposits and interbank transactions that public banks do not have. Public banks only have revenues related to financial intermediation (interest earned).

\subsection{Definition of variables}

Table 4 shows the definition of each variable included in the analysis. The description of each variable was made based on what is established by the "Superintendency of Banks of Ecuador" on its catalogue of accounts of the national financial system[2].

\subsection{Methods}

In this study, we used a reduced form equation where the dependent variable is the ratio of total revenues and total assets of each private bank. We chose to use this ratio because private banks in Ecuador not only have income from lending (interest earned) but also from charges for the use of some services such as interbank transfers, withdrawal of deposits, management of current accounts, issuance of credit card statements, among others. Other articles in the literature use the same approach regarding the choice of the dependent variable such as Bikker et al. (2012) and Stavarek and Repková (2014).

We follow Nathan and Neave (1989), Claessens and Laeven (2004) and Yildirim and Philippatos (2007) with the model to measure private banking competition by size in Ecuador setting the following equation expressed in logarithms:

$$
\begin{aligned}
& \ln \left(\mathrm{REV}_{i j t}\right)= \alpha+\beta_{1} \ln \left(\mathrm{PL}_{i j t}\right)+\beta_{2} \ln \left(\mathrm{PK}_{i j t}\right)+\beta_{3} \ln \left(\mathrm{PF}_{i j t}\right)+\gamma_{k} \ln \left(\mathrm{BSF}_{i j t}\right)+\sum_{t=1}^{t} \delta_{t} D_{t} \\
&+\varepsilon_{i j t} \\
& \ln \left(\mathrm{TR}_{i j t}\right)= \alpha+\beta_{1} \ln \left(\mathrm{PL}_{i j t}\right)+\beta_{2} \ln \left(\mathrm{PK}_{i j t}\right)+\beta_{3} \ln \left(\mathrm{PF}_{i j t}\right)+\gamma_{k} \ln \left(\mathrm{BSF}_{i j t}\right)+\sum_{t=1}^{t} \delta_{t} D_{t} \\
&+\varepsilon_{i j t} \\
& \varepsilon_{i j t}=\mu_{i j}+\varphi_{i j t}
\end{aligned}
$$

where $i$ represents each private bank, $j$ is the bank size and $t$ is every year. The dependent variable REV is the ratio between total income and total assets to have a price equation (output price); nevertheless, we use a measure of revenue to check the robustness of our

Table 3.

Number of observations per bank size for the sample with data based on years 2000 2015

\begin{tabular}{lccc}
\hline Size & Frequency & $(\%)$ & Cumulative \\
\hline Large & 65 & 16.97 & 16.97 \\
Medium & 117 & 30.55 & 47.52 \\
Small & 201 & 52.48 & 100 \\
Total & 383 & 100 &
\end{tabular}

Source: Superintendencia de Bancos del Ecuador (2016) 


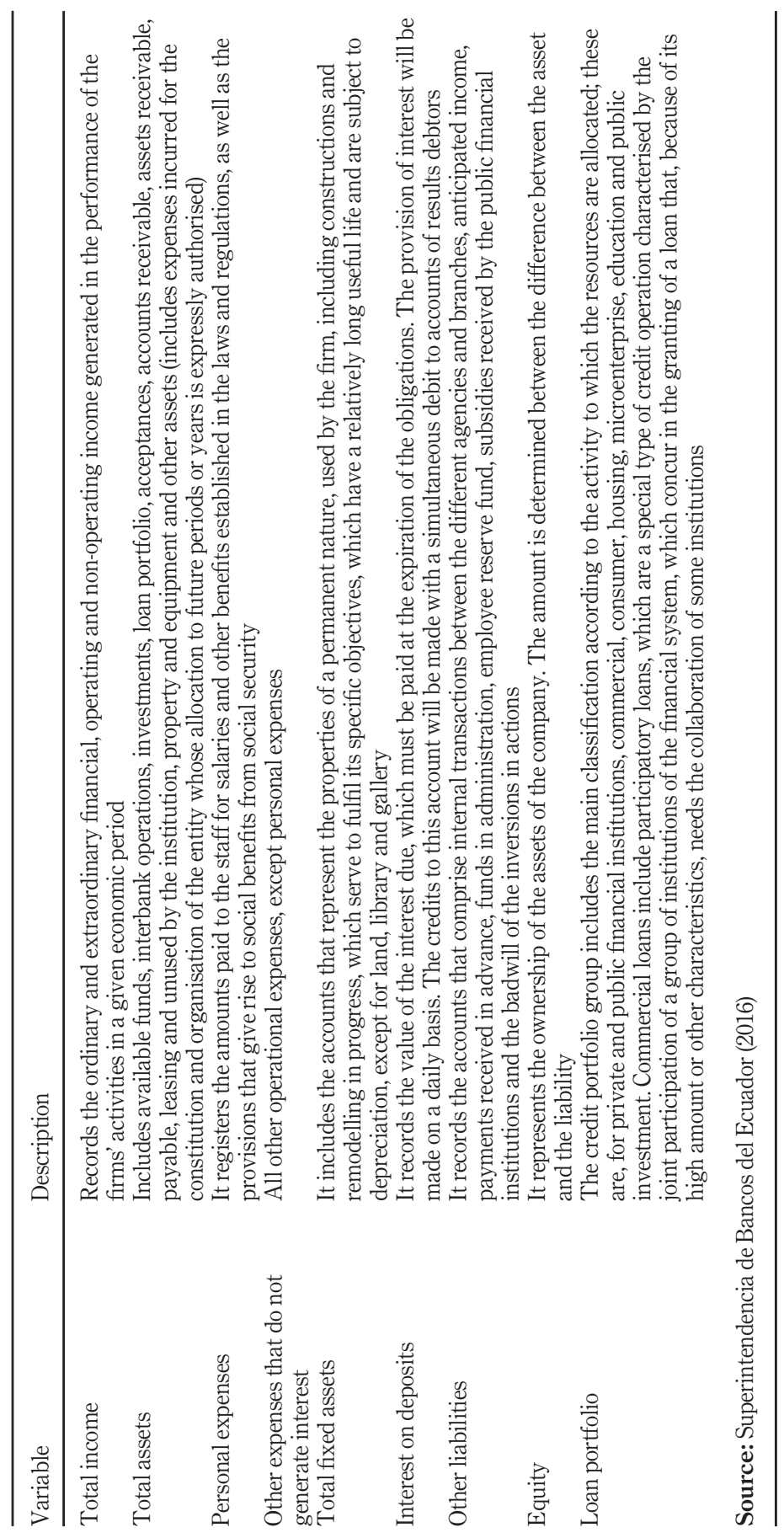

Intra-banking competition

303

Table 4

Definition of variables 
JEFAS 25,50

304

model; in this line, we include total revenues (TR) expressed as the sum of gross interest revenues and other operating non-interest revenues to have a revenue equation (Apergis et al., 2016). The independent variables are three input factors: labour, capital and deposits, where PL, PK and PF correspond to the three price inputs if all banks use these three productive factors. Thus, $\mathrm{PL}$ is the ratio between personal expenses and total assets as an approximation of the wage rate, PK is the ratio between the other expenses that do not generate interests and total fixed assets that include machinery, equipment, land, among others as a proxy of physical capital (Molyneux et al., 1994), PF is the ratio between interest expense on deposits and other liabilities, as a proxy for the average funding rate; these variables are used in line with the theoretical model proposed by Panzar and Rosse (1987). In addition, we have added a vector of specific factors BSF to be able to control for differences in risk and operational capacity; within this BSF vector, we find the following variables: liquidity (Liq) is the capacity to pay the obligations in the short run and is an approximation of solvency; leverage (Lev) is the ratio of equity to total assets as a proxy for the leverage, reflecting differences in the risk preferences across banking institutions (Bikker et al., 2012). Credit risk (Risk) is the ratio of net loans to total assets as an approximation of the credit risk, and fixed assets (FA) as a capacity indicator; additionally,, for scaled revenue and price equations we use the total assets (TA), and for unscaled equations, we do not use TA to check the robustness of our model. Finally, to control possible macroeconomic changes within each year, a year dummy $(D)$ has been created.

The model assumes a one-way error component as observed in equation (1), which denotes the unobservable effect of specific banks and also a random term that is not observed by the bank or the analyst. In agreement with the calculation of the $H$-statistic and the P-R model, the $H$-statistic will be equal to the sum of the income elasticities with respect to the three price inputs:

$$
H_{j}=\hat{\beta}_{1}+\hat{\beta}_{2}+\hat{\beta}_{3}
$$

Once the value of $H$ is obtained, the hypothesis tests are carried out to determine whether the value is consistent with the theory. To test the validity of the P-R model, in the sense that the market is in equilibrium, in the long run, we estimate an equation where the dependent variable is the return on assets (ROA):

$$
\begin{aligned}
\ln \left(\mathrm{ROA}_{i j t}\right)= & \alpha+\beta_{1} \ln \left(\mathrm{PL}_{i j t}\right)+\beta_{2} \ln \left(\mathrm{PK}_{i j t}\right)+\beta_{3} \ln \left(\mathrm{PF}_{i j t}\right)+\gamma_{k} \ln \left(\mathrm{BSF}_{i j t}\right)+\sum_{t=1}^{t} \delta_{t} D_{j t} \\
& +\varepsilon_{i j t}
\end{aligned}
$$

Because ROA can take negative values, this dependent variable is computed as $\ln (1+\mathrm{ROA})$ (Utrero-Gonzalez, 2004). It is assumed that in long-run equilibrium, the elasticity of profitability to changes in factor prices should be zero, i.e. change in input prices should not affect the profitability of financial intermediaries (Castellanos, 2010). The long-run balance of the private banking market is calculated as follows:

$$
E_{j}=\hat{\beta}_{1}+\hat{\beta}_{2}+\hat{\beta}_{3}
$$

To assess the long-run equilibrium, we perform a test where $E=0$. The equilibrium test in the long run is calculated using the Wald $F$ coefficient constraint test that tests whether $E=$ 0 or not. 
Our panel data set is an unbalanced panel with $N>T$, and similar to time series with a cross section (TSCS), they are exposed to have some characteristics that could difficult the econometric estimation with a traditional method such as ordinary least squares (OLS) because of heteroskedasticity, temporal autocorrelation or contemporary correlation between panels and unit root problems. Besides, Beck and Katz (1995) argue that the OLS estimations are not optimal in the presence of not spherical errors. The statistical tests used to allow us to know whether these problems are present in our sample and then choose the best econometric estimation technique for the model (these are available upon request). As we have detected some problems such as autocorrelation and heteroskedasticity in our sample, we use two alternative methods: feasible generalised least squares (FGLS) and panel correction standard errors (PCSE).

The FGLS method proposed by Parks (1967) and Kmenta (1986) allows the estimation of TSCS models in which the error term has grouped heteroskedasticity, contemporary correlation, and autocorrelation, but this method is not valid in situations when $N>T$ because this method needs a relative large $T$ with respect to $N$; in this line, this method is limited to TSCS research.

On the other hand, Beck and Katz (1995) proposed the PCSE method and demonstrate the superiority concerning the FGLS method in panel data with $N>T$; they found that the estimations on FGLS had problems with the sub estimation of the errors, with minimum efficiency improvements about the OLS method. They also found the superiority of the PCSE method with respect to the FGLS method in different conditions of heteroskedasticity and contemporary correlation.

The PCSE method could correct the first-order autocorrelation with a previous transformation proposed by Prais and Winsten (1954). Our data set is composed of banks with different characteristics in risk, loans, catchments and size, it is assumable the existence of different autoregressive coefficient for each panel. However, Beck and Katz (1995) recommend to calculating a similar autoregressive coefficient for all panels, because the interest parameters $\beta$ do not change for each cross unit.

\section{Results}

We estimate equation (7) by POLS, FE, RE, FGLS and PCSE; the last two methods are used to correct possible problems with autocorrelation and heteroskedasticity in the OLS estimations. Table 5 shows the econometric results of the competition degree from 2000 to 2015 using an unscaled equation. We show the estimations from five different econometric methods; nevertheless, we only discuss those from PCSE estimation because of the methodological implications discussed in Section 2.

We found that the $H$-statistic for large banks was estimated at 0.14 ; this result is statistically significantly different from one in the Wald $F$ test and the null hypothesis $H=1$ was rejected, which suggests that large banks operate in a monopolism environment. Second, the $H$-statistic for medium-sized banks is 0.55 ; this result is statistically significantly different from zero, and also from one, the null hypothesis $H=0$ was rejected as well as the hypothesis $H=1$, showing that medium-sized banks operate in a monopolistic competition. For small banks, the $H$-statistic is 0.58 ; also the hypotheses $H=0$ and $H=1$ are rejected, which means that small banks operate in a monopolistic competition similar to mediumsized banks.

According to the input prices, all the methodologies reported in Table 5 have the same results in PL, PF, and PK in terms of sign and significance, being the estimation of the $H$ statistic robust to any of the methods applied. In this sense, for medium-sized banks, the input prices are positive and significant; additionally, the PL (labour input) has the major 
JEFAS

25,50

306
Table 5.

P-R model: private banking sector aggregate results in Ecuador by size for the period 2000-2015
된

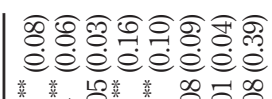

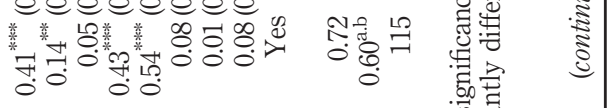

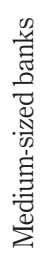

됟

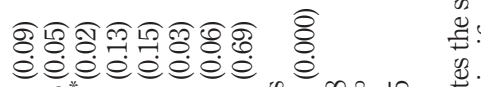

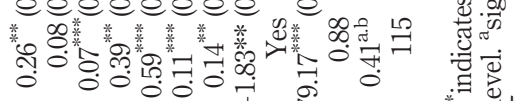

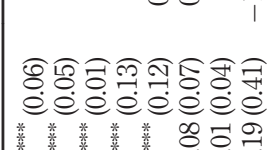

○

ㄴ.

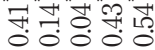

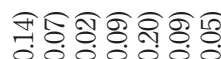

됭

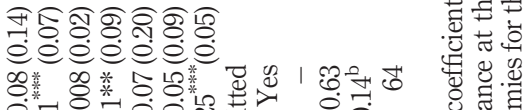

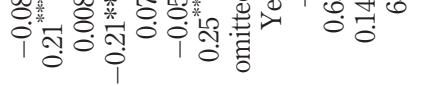

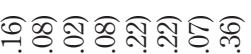

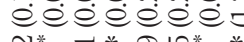

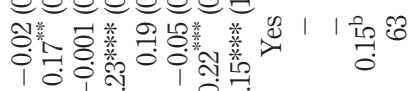

10i

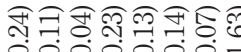

雚

됟

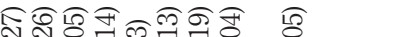

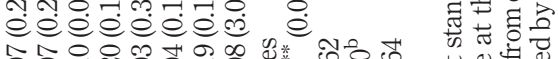

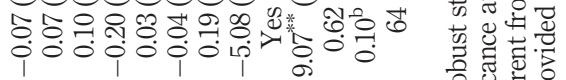

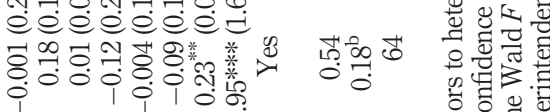

ठีฐ

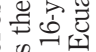

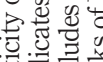

突:

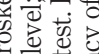

焉

을

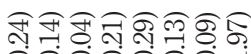

èejeè-

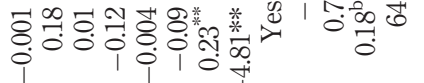

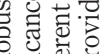

대을

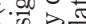

空

, w

.

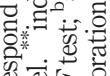

$\Rightarrow$ 年

08

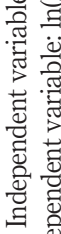

.

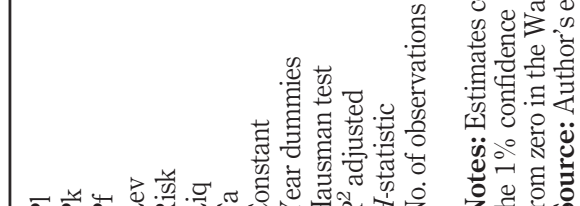




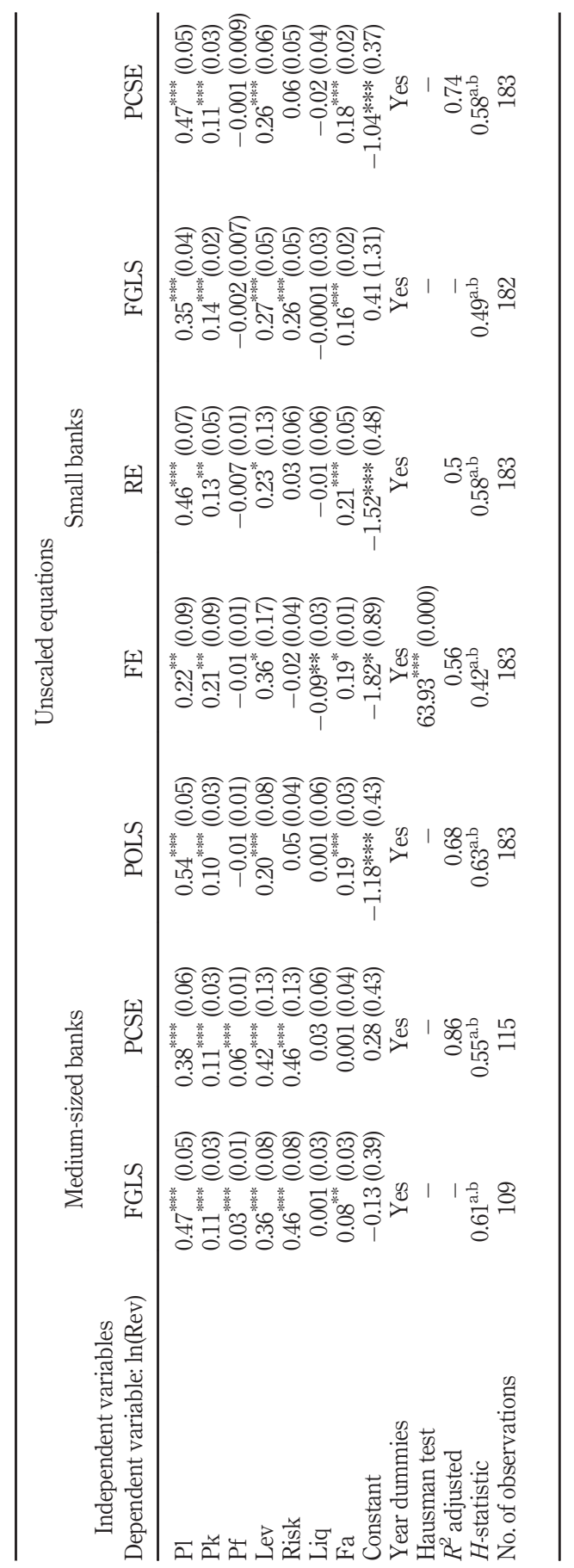

Intra-banking competition 
JEFAS

25,50

contribution to revenue (0.38), meaning that these banks are intensive in labour. For large banks, we found that only the PK input factor is positive and significant, meaning that are intensive in physical capital and not in labour or funding rate. For small banks, the prices of labour and capital are statistically significant and positive, implying that these two variables contribute to increasing revenue; the price of funds that is negative and not significant at standard levels is very close to zero and shows that the cost of the capital (money loans) does not have a significant influence on revenue.

Another important result from Table 5 is the coefficient of capacity indicator (FA); it is positive and significant for large and small banks, while for medium-sized banks, this variable is not significant. This result could imply that it seems to be a difference in capacity (fixed assets) between banks that belong to the same group. On the other hand, the leverage (Lev) is significant for all bank size groups but only negative for large banks, suggesting that debt is not the way to increase investments and revenue, but for medium-sized and small banks, the debt is positively related to revenue, and more debt which is invested improves the revenue. Finally, risk and liquidity (Liq) have the same effect on large and small banks; those variables are positive (Risk) and negative (Liq) but not significant, suggesting that these variables do not influence significantly on output prices and revenue. However, for medium-sized banks, the risk is positive and significant, meaning that more loans to total assets increase output prices and revenues.

Based on the discussion on Bikker et al. (2012) and Apergis et al. (2016), who mention that only unscaled equations provide a valid measure of banking competition using the P-R model, it results necessary to check the robustness of our findings by estimating scale equations to see whether the results change. To implement this, we include in equation (7) the variable total assets (Ta).

Table 6 contains the estimation results when we account for the scale effect. Similar to the unscaled results, we only discuss those from PCSE estimation because of the methodological implications discussed in Section 2. In this line, we found that the input prices (PL, PK and PF) have the same sign and significance obtained in the unscaled results; additionally, the $H$-statistic for large banks is 0.13 and it is statistically significantly different from one in the Wald $F$ test; the null hypothesis $H=1$ was rejected, which suggests that large banks operate in a monopolism environment as in unscaled equation results. Also, the $H$-statistic for medium-sized banks is 0.57 ; this result is statistically significantly different from zero, and also from one, the null hypothesis $H=0$ was rejected as well as the hypothesis $H=1$, showing that medium-sized banks operate in a monopolistic competition. For small banks, the $H$-statistic is 0.67 ; also the hypotheses $H=0$ and $H=1$ were rejected, which means that small banks operate in a monopolistic competition similar to mediumsized banks. These results are in line with those obtained in Apergis et al. (2016) and Sun (2011), who mentions that the estimated results in scaled and unscaled revenue equations are quite similar and the competition degree does not change from one to other.

As we know, the P-R model is only valid if the market is in long-run equilibrium. This long-run equilibrium is usually tested with a model in which the dependent variable is ROA and the independent variables are the same as in the competitive model. The test for the long-run equilibrium is shown in Tables 7 and 8 for unscaled and scaled revenue equations and is estimated with the Wald coefficient restriction test using equations 9 and 10 .

The null hypothesis for long-run equilibrium in large, medium and small banks $\left(E_{j}=\hat{\beta}_{1}+\hat{\beta}_{2}+\hat{\beta}_{3}=0\right)$ was not rejected for all bank sizes, the five methodologies and unscaled and scaled revenue equations. The null hypothesis of the coefficients being equal to zero cannot be rejected confirming that large, medium and small banks were in equilibrium during the period from 2000 to 2015. The argument behind the equilibrium test 


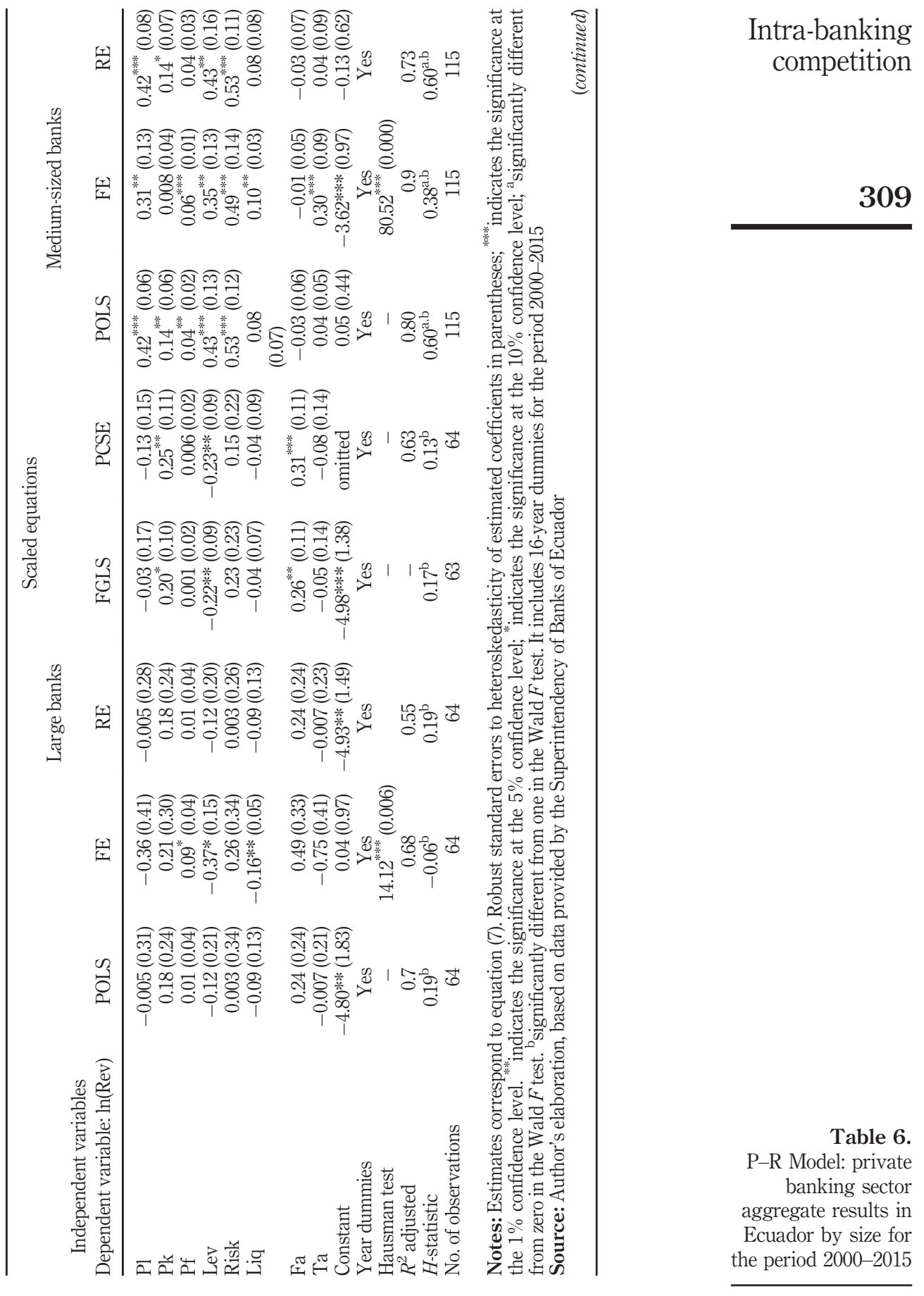


JEFAS

25,50

310

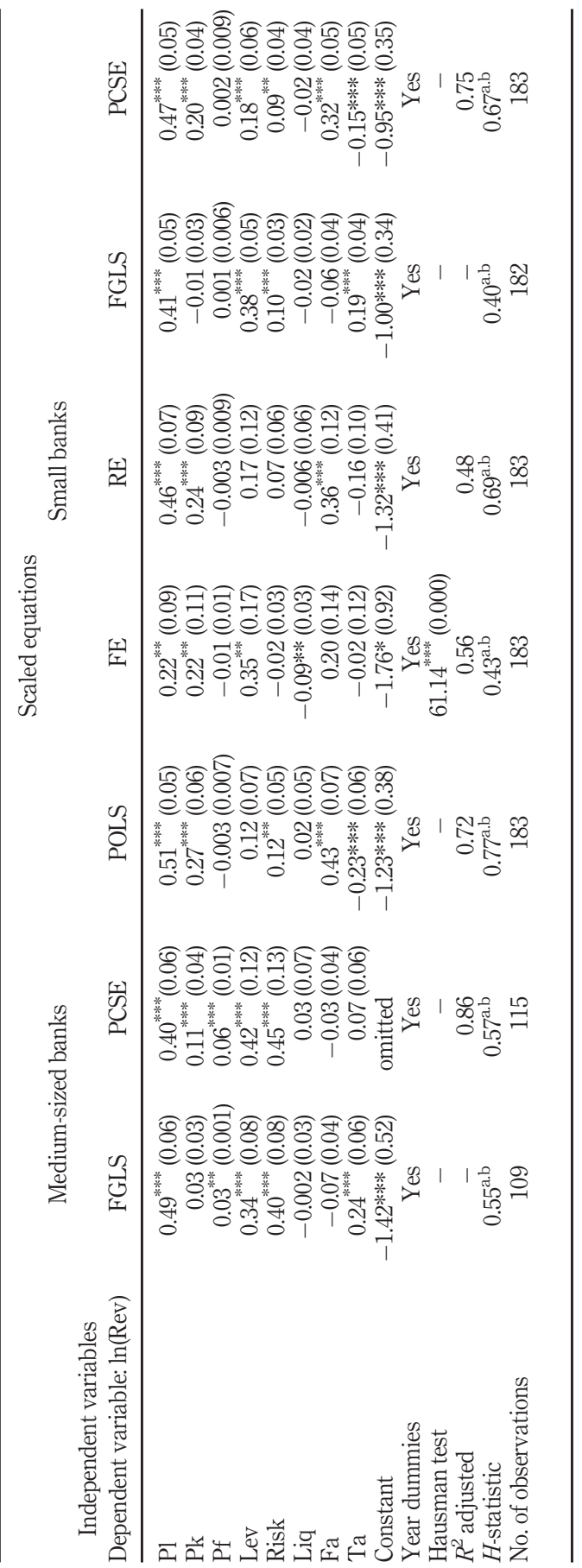

Table 6. 


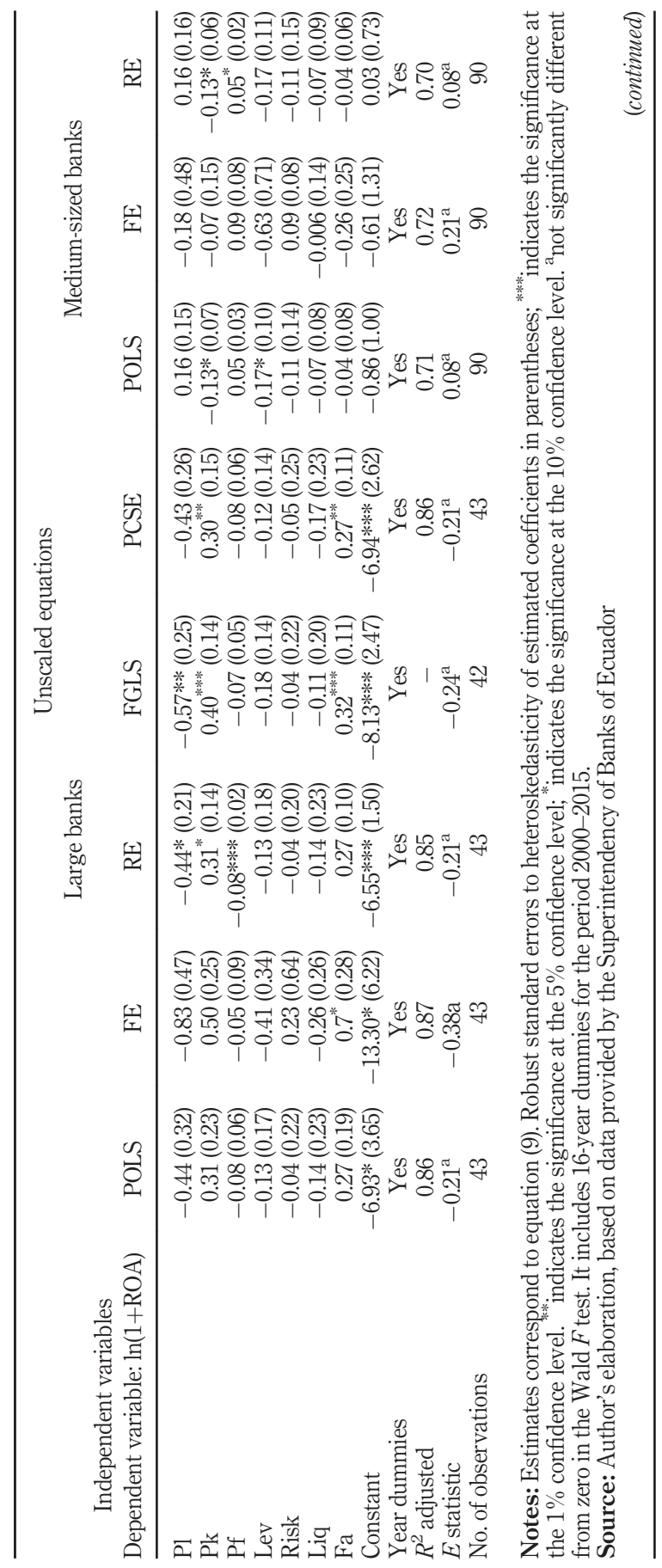

Intra-banking competition

Table 7.

Equilibrium test: private banking sector aggregate results in Ecuador by size for the period 2000-2015 
JEFAS

25,50

312

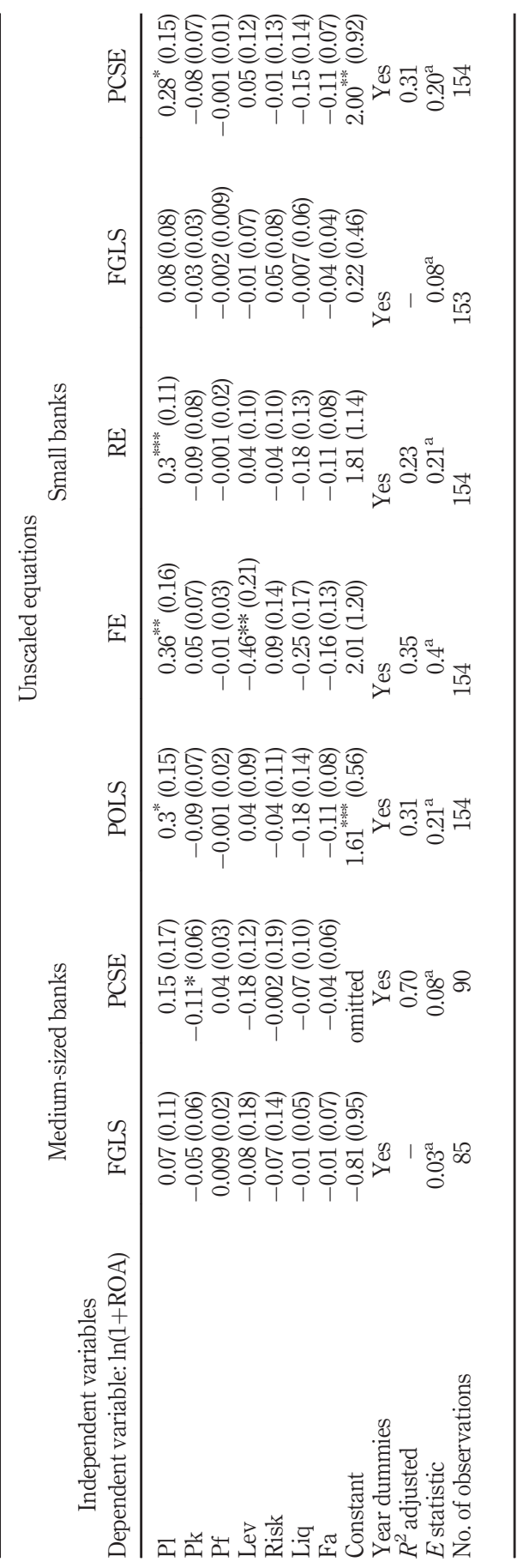

Table 7. 


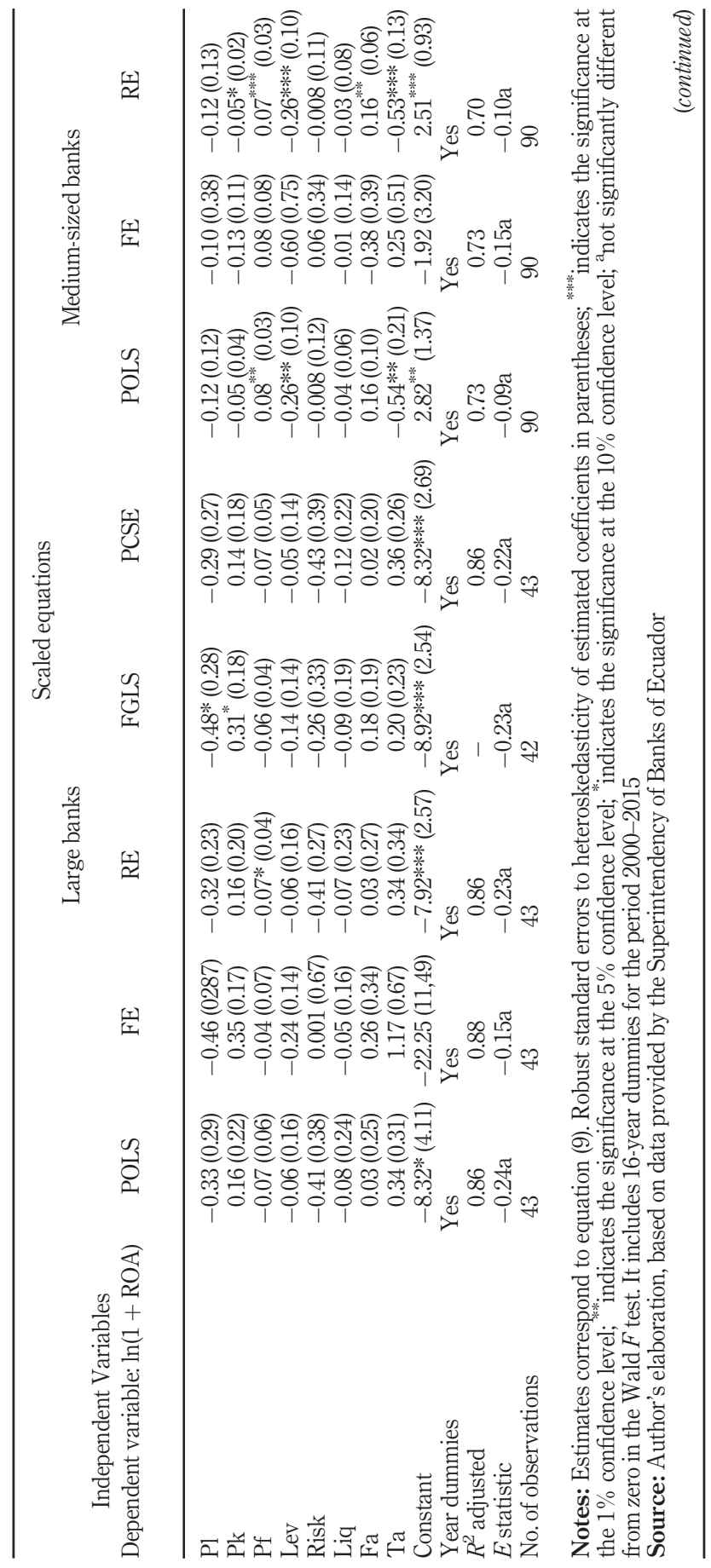

Intra-banking competition

Table 8. Equilibrium test: private banking sector aggregate results in Ecuador by size for 2000-2015 
JEFAS

25,50

314

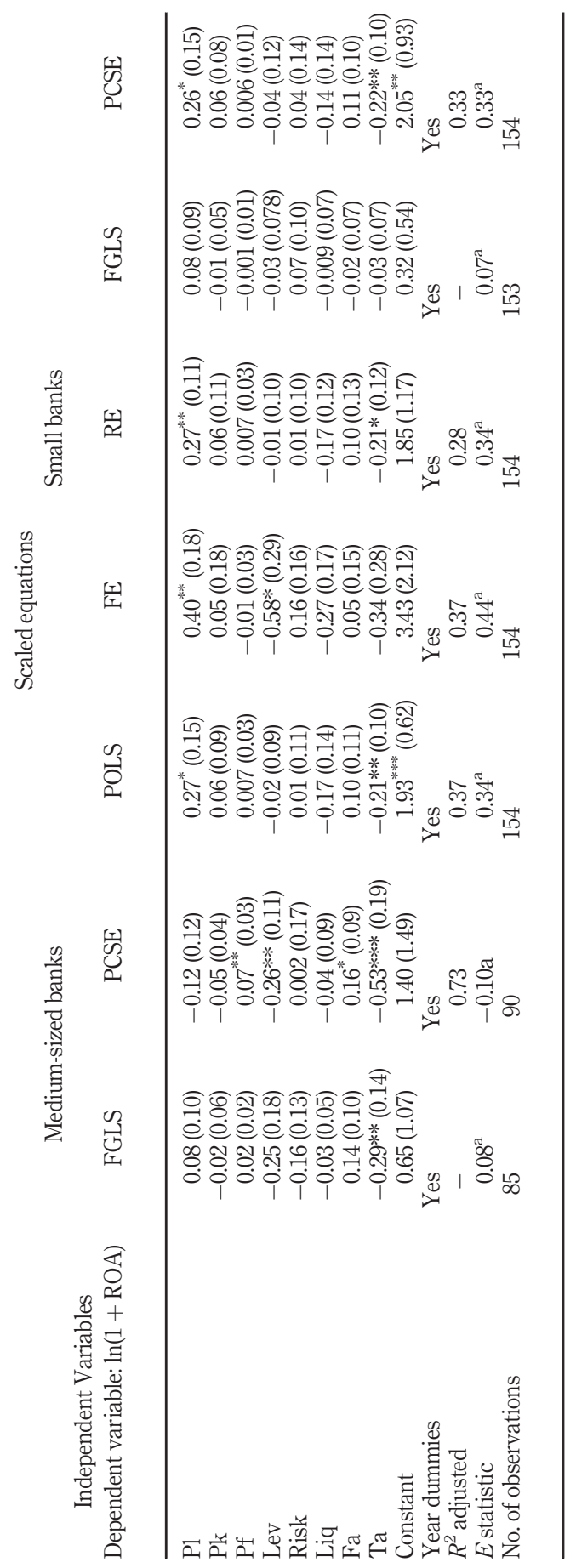

Table 8. 
is that in the long-run equilibrium the forces of market equalise ROA among homogeneous banks and changes in input prices do not affect the returns on assets (Shaffer, 1985).

\subsection{Robustness check}

To assess the robustness of our specification in equation (7) and once decided that PCSE is the method that we use to obtain the competition degree, Table 9 shows the results of PCSE estimations using price equation (7) in Model 1 and estimations using revenue equation (8) in model 2 for unscaled equations.

Our results obtained in Model 2 confirm our evidence in Model 1, particularly we get that the $H$-statistic is close to 0 for large banks and do not reject the null hypothesis of monopoly but reject the null hypothesis of perfect competition. We also find that medium-sized and small banks are in monopolistic competition because the $H$-statistic rejects the null hypothesis of monopoly and perfect competition. In terms of the input prices, our results confirm the sign and significance in all bank sizes. Finally, we do not find differences in the estimation of the $H$ statistic comparing price and revenue equations on unscaled methodology.

\section{Conclusion and discussion}

The main contribution of this study is to provide evidence on the different competitive environments that private banks, classified by size, operate in Ecuador. We decided to split the data into three size groups, large, medium-sized and small banks, because these groups operate in different loans segments and based on a sample of firms of widely different sizes within a single market may be intrinsically unsuitable to apply the P-R test as mentioned by Bikker et al. (2012). In addition, we use official national data provided by the regulatory institution SB and finally this is the first attempt that analyses competition by size in the Ecuadorian private banking sector.

This paper has not found evidence of a non-competitive market structure for small and medium-sized banks; according to this, these groups compete in the banking sector as in monopolistic competition. However, for large banks, we found evidence supporting a monopolism market.

Our conclusions suggest that medium-sized and small groups of banks are more competitive than large banks; this evidence is in concordance with Bikker et al. (2012) where they separate large and small banks and compare the $H$-statistic of this two groups and found that in some cases large banks operate on monopolism market, and also they argue that the coexistence of banks of different sizes within the same market is strong evidence of either disequilibrium or locally constant average cost and since constant average cost and disequilibrium undermine the reliability of the P-R test, a sample of firms of widely differing sizes within a single market may be intrinsically unsuitable for the application of the P-R test.

However, Yildirim and Philippatos (2007) argue that large banks in Argentina, Brazil, Chile, Peru and Uruguay operate in a relatively more competitive environment compared to small banks, although in Ecuador they not found differences in the degree of competition between large and small banks. A possible interpretation is that large banks can exercise some market power because of their strong competitive position in local retail markets and enjoy a certain degree of spatial differentiation accompanied by it.

Finally, similar to Sabir and Qayyum (2018), we found robust evidence that shows that unscaled and scaled revenue equations or price equations conduct to the same results of competition degree; these results are in accordance with Apergis et al. (2016) but not with Bikker et al. (2012) who mention that only an unscaled revenue equation yields a valid measure for competitive conduct. Our results did not reveal any significant differences in the

Intra-banking competition

$-$


JEFAS

25,50

316
Table 9.

P-R Model: private banking sector aggregate results in Ecuador by size for the period 2000-2015 using the PCSE method

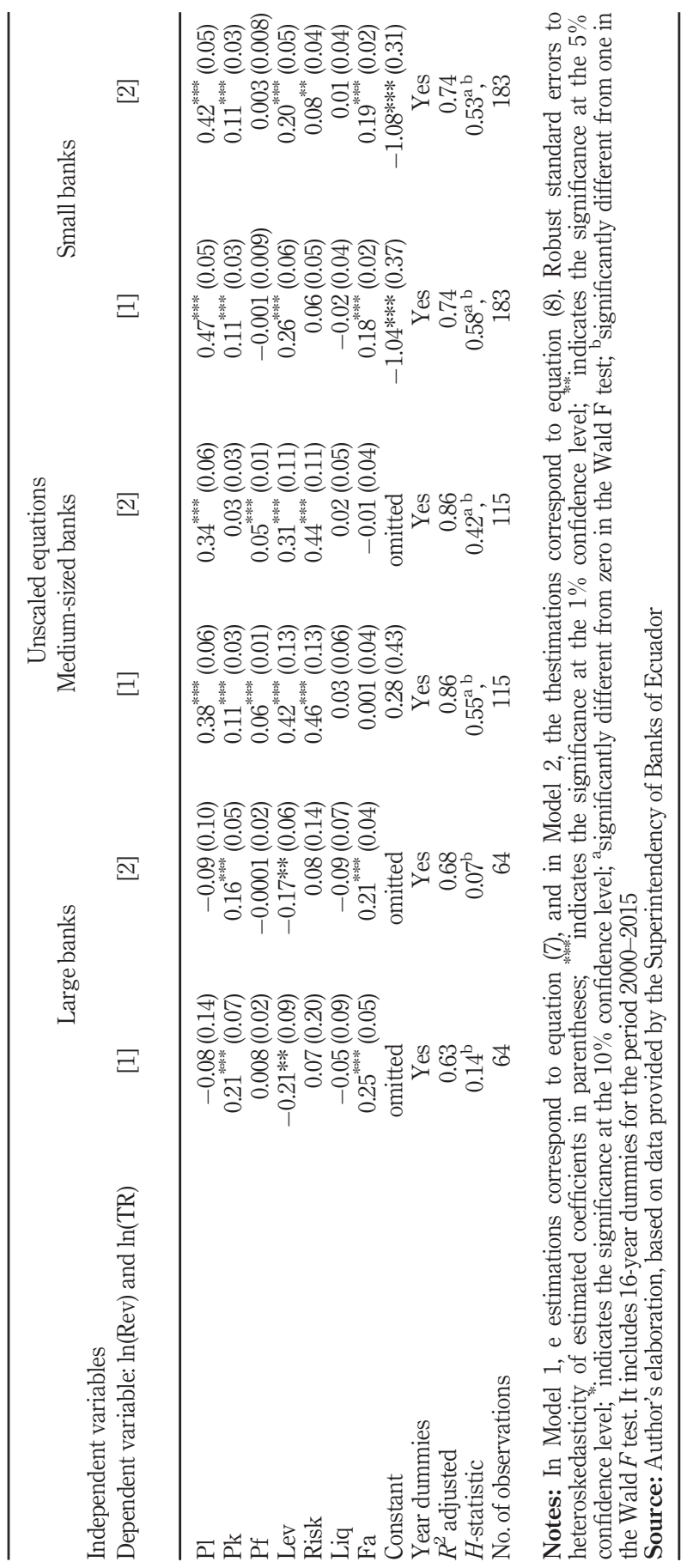


magnitude of the relevant estimations between the scaled and the unscaled modelling approaches. Finally, we found that PCSE methodology fits better than POLS, FE, RE and FGLS methods; also, the results between the five methodologies did not change when we compare unscaled price and revenue equations.

These results are different compared to other countries that used the same methodology such as Bikker et al. (2012), Yildirim and Philippatos (2007) and De Bandt and Davis (2000); it could be because they classified the banks in two sizes, only large and smalls and also include the public banking sector. Finally, we found that large, medium-sized and small banks were in long-run equilibrium meaning that the $\mathrm{P}-\mathrm{R}$ model is correctly adjusted in the estimation and giving evidence of bank stability in each size group.

Given the results obtained, one of the important targets for policymakers is large banks as this study shows that they are operating in a monopolism market. Since 2001, the group of large banks has been confirmed by the same four banks until the end of the research period (2015). Behaviour that may make one think that there could be collusion among the firms to reinforce market power, only to prevent, restrict or distort competition, against the economic efficiency or the welfare of consumers (Superintendencia de Control del Poder de Mercado de Ecuador, 2011).

The durability of market power has gained significant relevance in antitrust legislation. In many cases, dominant companies have erected entry barriers to exclude new rivals, in which the average cartel has been found to last more than eight years and others have survived for at least 40 years. This evidence shows that anti-competitive behaviour can often be sustained over long periods of time and overcome the incentive of companies to cheat on cartels and the incentive to expand and compete out of monopoly profits (Baker, 2017). In this sense, there is scope for future research on designing and implementing policies to guarantee competitive behaviour in the private banking system.

\section{Notes}

1. For a detailed review of empirical studies analysing competition in the banking sector in Latin American countries, see Camino-Mogro and Armijos-Bravo (2018), and for a summary of published empirical P-R studies, see Bikker et al. (2012).

2. Descriptive statistics of the main variables are available on request.

\section{References}

Anginer, D., Demirguc-Kunt, A. and Zhu, M. (2014), "How does competition affect bank systemic risk?", Journal of Financial Intermediation, Vol. 23 No. 1, pp. 1-26.

Apergis, N., Fafaliou, I. and Polemis, M. (2016), "New evidence on assessing the level of competition in the European Union banking sector: a panel data approach”, International Business Review, Vol. 25 No. 1, pp. 395-407.

Bain, J. (1951), "Relation of the profit rate to industry concentration: American manufacturing, 19361940", The Quarterly Journal of Economics, Vol. 65 No. 3, pp. 293-324.

Baker, J.B. (2017), Market Power in the U.S. economy Today, Washington, DC Center for Equitable Growth.

Barbosa, K., De Paula Rocha, B. and Salazar, F. (2015), “Assessing competition in the banking industry: a multi-product approach", Journal of Banking and Finance, Vol. 50, pp. 340-362.

Beck, N. and Katz, J. (1995), "What to do (and not to do) with time-series cross-section data", American Political Science Review, Vol. 89 No. 3, pp. 634-647. 
JEFAS 25,50

318
Berger, A. and Black, L. (2011), "Bank size, lending technologies, and small business finance”, Journal of Banking and Finance, Vol. 35 No. 3, pp. 724-735.

Berger, A., Miller, N., Petersen, M., Rajan, R. and Stein, J. (2005), "Does function follow organizational form? Evidence from the lending practices of large and small banks", Journal of Financial Economics, Vol. 76 No. 2, pp. 237-269.

Bikker, J. and Haaf, K. (2002), "Competition, concentration and their relationship: an empirical analysis of the banking industry”, Journal of Banking and Finance, Vol. 26 No. 11, pp. 2191-2214.

Bikker, J. and Spierdijk, L. (2017), Handbook of Competition in Banking and Finance, Edward Elgar Publishing.

Bikker, J., Shaffer, S. and Spierdijk, L. (2012), “Assessing competition with the Panzar-Rosse model: the role of scale, costs, and equilibrium”, Review of Economics and Statistics, Vol. 94 No. 4, pp. 1025-1044.

Buchs, T. and Mathisen, J. (2005), "Competition and efficiency in banking: behavioral evidence from Ghana”, IMF Working Paper.

Camino-Mogro, S. and Armijos-Bravo, G. (2018), "Assessing competition in the private banking sector in Ecuador: an econometric approach with the Panzar-Rosse model”, Cuadernos de Economía, Vol. 41 No. 117, pp. 225-240.

Castellanos, G.D. (2010), "Estructura y poder del sector bancario de Guatemala”, Gerencialidad SocioEmpresarial, Vol. 30, pp. 34-39.

Claessens, S. and Laeven, L. (2004), "What drives bank competition? Some international evidence", Journal of Money, Credit, and Banking, Vol. 36 No. 3b, pp. 563-583.

De Bandt, O. and Davis, P. (2000), "Competition, contestability and market structure in European banking sectors on the eve of EMU”, Journal of Banking and Finance, Vol. 24 No. 6, pp. 1045-1066.

De Haan, J. and Poghosyan, T. (2012), "Bank size, market concentration, and bank earnings volatility in the US”, Journal of International Financial Markets, Institutions and Money, Vol. 22 No. 1, pp. 35-54.

Durán, V., Quirós, J. and Rojas, M. (2009), Análisis de la Competitividad Del Sistema Financiero Costarricense, Banco Central de Costa Rica, Departamento De Análisis y Asesoría Económica.

Gelos, R. and Roldós, J. (2004), "Consolidation and market structure in emerging market banking systems”, Emerging Markets Review, Vol. 5 No. 1, pp. 39-59.

Goddard, J. and Wilson, J. (2009), "Competition in banking: a disequilibrium approach”, Journal of Banking and Finance, Vol. 33 No. 12, pp. 2282-2292.

Kmenta, J. (1986), Elements of Econometrics, (2nd ed.). New York, NY: Macmillan.

Moch, N. (2013), "Competition in fragmented markets: new evidence from the German banking industry in the light of the subprime crisis", Journal of Banking and Finance, Vol. 37 No. 8, pp. 2908-2919.

Molyneux, P., Lloyd-Williams, D. and Thornton, J. (1994), "Competitive conditions in European banking”, Journal of Banking and Finance, Vol. 18 No. 3, pp. 445-459.

Nathan, A. and Neave, E.H. (1989), “Competition and contestability in Canada's financial system: empirical results”, The Canadian Journal of Economics, Vol. 22 No. 3, pp. 576-594.

Nguyen, T., Stewart, C. and Matousek, R. (2018), "Market structure in the Vietnamese banking system: a non-structural approach”, Journal of Financial Regulation and Compliance, Vol. 26 No. 1, pp. 103-119.

Panzar, J. and Rosse, J. (1987), “Testing for 'monopoly' equilibrium”, The Journal of Industrial Economics, Vol. 35 No. 4, pp. 443-456.

Parks, R. (1967), "Efficient estimation of a system of regression equations when disturbances are both serially and contemporaneously correlated", Joumal of the American Statistical Association, Vol. 62 No. 318, pp. 500-509.

Perrakis, S. (1991), “Assessing competition in Canada's financial system: a note”, The Canadian Journal of Economics, Vol. 24 No. 3, pp. 727-732. 
Prais, S. and Winsten, C. (1954), "Trend estimators and serial correlation”, Chicago: Cowles Commission Discussion Paper, Vol. 383, pp. 1-26.

Sabir, S. and Qayyum, A. (2018), "Competition in the banking sector of Pakistan: evidence from unscaled and scaled revenue equations", Journal of Economic Cooperation and Development Vol. 39 No. 1, pp. 19-37.

Salgado, W. (2010), "Banca de desarrollo en el Ecuador", in Unidas, N. (Ed.), Santiago de Chile, Chile, CEPAL - Serie Financiamiento del desarrollo No. 232.

Shaffer, S. (1985), "Competition, economies of scale, and diversity of firm sizes", Applied Economics, Vol. 17 No. 3, pp. 467-476.

Shaffer, S. and Spierdijk, L. (2015), "The Panzar-Rosse revenue test and market power in banking", Journal of Banking and Finance, Vol. 61, pp. 340-347.

Stavarek, D. and Repková, I. (2014), "Estimation of the competitive conditions in the Czech banking sector", Acta Universitatis Agriculturae et Silviculturae Mendelianae Brunensis, Vol. 59 No. 2, pp. 299-306.

Stever, R. (2007), "Bank size, credit and the sources of bank market risk”, BIS Working Paper no. 238.

Sun, Y. (2011), "Recent developments in European bank competition”, IMF Working Paper no. 11/146 (pp. 1-25). International Monetary Fund.

Superintendencia de Bancos del Ecuador (2016), "Superintendencia de bancos", Available at: www. superbancos.gob.ec/practg/sbs_index?vp_art_id=9354\&vp_tip=2\#1 (accessed September 5, 2016).

Superintendencia de Control del Poder de Mercado de Ecuador (2011), Ley de Regulación, L.O. Control de Poder de Mercado, Quito.

Uchida, H., Udell, G. and Watanabe, W. (2008), "Bank size and lending relationships in Japan”, Journal of the Japanese and International Economies, Vol. 22 No. 2, pp. 242-267.

Utrero-Gonzalez, N. (2004), "Banking competition in UK and Spain: is there a Euro effect?", FMA European Conference, Zurich.

Uzcátegui-Sánchez, C., Camino-Mogro, S. and Moran-Cruz, J. (2018), "Estructura de mercado del sistema bancario ecuatoriano: concentración y poder de mercado”, Cumbres, Vol. 4 No. 1, pp. 49-62.

Vera-Gilces, P., Camino-Mogro, S., Ordeñana-Rodríguez, X. and Cornejo-Marcos, G. (2020), "A look inside banking profitability: evidence from a dollarized emerging country", The Quarterly Review of Economics and Finance, Vol. 75, pp. 147-166.

Yildirim, H.S. and Philippatos, G. (2007), "Restructuring, consolidation and competition in Latin American banking markets”, Journal of Banking and Finance, Vol. 31 No. 3, pp. 629-639.

\section{Corresponding author}

Segundo Camino-Mogro can be contacted at: segundo.camino@gmail.com

For instructions on how to order reprints of this article, please visit our website:

www.emeraldgrouppublishing.com/licensing/reprints.htm

Or contact us for further details: permissions@emeraldinsight.com 